\title{
Low-Dose Colchicine in Coronary Artery Disease - Systematic Review and Meta-Analysis -
}

\author{
Ana Mafalda Abrantes, MD; Beatriz Nogueira-Garcia, MD; Mariana Alves, MD; \\ Dúlio Teixeira Passos, MD; Dulce Brito, MD, PhD; \\ Fausto J. Pinto, MD, PhD; Daniel Caldeira, MD, PhD
}

\begin{abstract}
Background: Recent studies have revealed the benefits of using colchicine, a drug with anti-inflammatory properties, in coronary artery disease (CAD). This study systematically reviewed the benefits and risks of low-dose colchicine in patients with CAD.

Methods and Results: We searched for randomized controlled trials (RCTs) in MEDLINE, the Cochrane Central Register of Controlled Trials (CENTRAL), and Web of Science databases (March 2020). Efficacy and safety outcomes were evaluated. Estimates are expressed as risk ratios (RRs) and $95 \%$ confidence intervals $(95 \% \mathrm{Cls})$. Heterogeneity was assessed with $\mathrm{I}^{2}$ test. Confidence in the pooled evidence was appraised using the GRADE framework. Colchicine reduced the rate of major adverse cardiovascular events (RR 0.65; 95\% Cl 0.49-0.86; 6 RCTs; I $2=50 \% ; 11,718$ patients; GRADE, moderate confidence), acute coronary syndrome (RR 0.64; 95\% Cl 0.46-0.90; I²=47\%; 7 RCTs; 11 ,955 patients; GRADE, very low confidence), stroke (RR 0.49; 95\% Cl 0.30-0.78; $\mathrm{I}^{2}=0 \%$; 6 RCTs; 11,896 patients; GRADE, moderate confidence), and cardiovascular interventions (RR 0.61; 95\% Cl 0.42-0.89; $I^{2}=40 \% ; 4$ RCTs; 11,284 patients; GRADE, high confidence). Colchicine did not increase the risk of adverse events, except for gastrointestinal events (RR 1.54; $95 \% \mathrm{Cl} 1.11-2.13 ; I^{2}=72 \%$; 9 RCTs; 12,374 patients; GRADE, very low confidence).
\end{abstract}

Conclusions: Low-dose colchicine in patients with CAD is associated with beneficial effects on prognosis, although an increased risk of gastrointestinal events was confirmed.

Key Words: Atherosclerosis; Colchicine; Coronary artery disease; Inflammation

C ardiovascular diseases are a major cause of morbidity and mortality worldwide. ${ }^{1}$ An important share of the burden of cardiovascular diseases relates to atherosclerosis, which is a process that involves inflammatory cells. Inflammation can accelerate and trigger complications of the atherosclerotic process. ${ }^{2}$ Therefore, it is not unexpected that old drugs targeting inflammation, such as colchicine, could be investigated for this cardiovascular indication.

Colchicine has anti-inflammatory properties ${ }^{3}$ and is widely used in the treatment of acute gout, as well as in Behçet's disease, pericarditis, primary biliary cirrhosis, and familiar Mediterranean fever. ${ }^{4}$ Orally administered colchicine has an estimated bioavailability of $44 \%$, reaches peak plasma concentration in $1 \mathrm{~h}$, and has a predominantly hepatic elimination. ${ }^{5}$ While in the circulation, colchicine concen- trates in leukocytes, where it interferes with the kinetics of the cytoskeletal microtubules by inhibiting mitosis, and so inhibiting leukocyte motility, impairing inflammation mediated by these cells.

Results regarding the benefits of low-dose colchicine in patients with coronary artery disease (CAD) are contentious. ${ }^{3}$ Therefore, the aim of this study was to systematically review randomized controlled trials (RCTs) evaluating the prognostic effects of low-dose colchicine in patients with CAD.

\section{Methods}

This systematic review followed the recommendations of the Preferred Reporting Items for Systematic Reviews and MetaAnalyses (PRISMA) ${ }^{6}$ and was registered in PROSPERO

Received May 24, 2021; accepted May 25, 2021; J-STAGE Advance Publication released online July 15, 2021 Time for primary review: 1 day

Internal Medicine Department 2 (A.M.A., D.T.P.), Cardiology Department (B.N.-G., D.B., F.J.P., D.C.), Santa Maria Hospital Northern Lisbon University Hospital Center (CHULN), Lisbon; Internal Medicine Department 3, Pulido Valente Hospital Northern Lisbon University Hospital Center (CHULN), Lisbon (M.A.); and Clinical and Therapeutic Pharmacology Laboratory, Faculty of Medicine (M.A., D.C.), Institute of Molecular Medicine, Faculty of Medicine (M.A.), Cardiovascular Center (D.B., F.J.P., D.C.), Academic Medical Center of Lisbon, Faculty of Medicine (D.B., F.J.P., D.C.), University of Lisbon, Lisbon, Portugal

Mailing address: Daniel Caldeira, MD, PhD, Cardiovascular Center, University of Lisbon, Academic Medical Center of Lisbon, Faculty of Medicine, University of Lisbon, Prof. Egas Moniz Avenue, Lisbon 1649-028, Portugal. E-mail: dgcaldeira@hotmail.com

All rights are reserved to the Japanese Circulation Society. For permissions, please e-mail: cr@j-circ.or.jp

ISSN-2434-0790 


\begin{tabular}{|c|c|c|c|c|c|c|c|c|c|}
\hline Reference & Location & Condition & Main endpoint & $\begin{array}{c}\text { Total no. } \\
\text { participants } \\
\text { (no. colchicine, } \\
\text { control groups) }\end{array}$ & $\begin{array}{c}\text { Mean } \\
\text { age } \\
\text { (years) }\end{array}$ & $\begin{array}{l}\text { No. (\%) } \\
\text { women }\end{array}$ & $\begin{array}{c}\text { Mean } \\
\text { BMI } \\
\left(\mathrm{kg} / \mathrm{m}^{2}\right)\end{array}$ & Smokers & $\begin{array}{l}\text { Hyper- } \\
\text { tension }\end{array}$ \\
\hline $\begin{array}{l}\text { O'Keefe } \\
\text { et al9 }\end{array}$ & US & CAD & $\begin{array}{l}\text { Angiographic } \\
\text { restenosis }\end{array}$ & $\begin{array}{l}197 \text { (colchicine } \\
130, \text { placebo } 67 \text { ) }\end{array}$ & $\begin{array}{l}\text { Colchicine } \\
59.0, \\
\text { placebo } \\
62.0\end{array}$ & $\begin{array}{l}\text { Colchicine } \\
19(14.6), \\
\text { placebo } \\
9(13.4)\end{array}$ & NA & NA & NA \\
\hline $\begin{array}{l}\text { Raju } \\
\text { et al10 }\end{array}$ & Australia & $\begin{array}{l}\text { ACS or } \\
\text { AIS }\end{array}$ & $\Delta \mathrm{hs}-\mathrm{CRP}$ & $\begin{array}{l}80 \text { (colchicine } 40^{A}, \\
\text { placebo } 40^{\mathrm{B}} \text { ) }\end{array}$ & $\begin{array}{l}\text { Colchicine } \\
57.2 \\
\text { placebo } \\
57.2\end{array}$ & $\begin{array}{l}\text { Colchicine } \\
6(15.0), \\
\text { placebo } \\
3(0.8)\end{array}$ & NA & $\begin{array}{l}\text { Colchicine } \\
31(77.5), \\
\text { placebo } \\
32(80.0)\end{array}$ & $\begin{array}{l}\text { Colchicine } 19 \\
(47.5), \\
\text { placebo } 15 \\
(37.5)\end{array}$ \\
\hline $\begin{array}{l}\text { Deftereos } \\
\text { et } \mathrm{al}^{3}\end{array}$ & NA & CAD & $\begin{array}{l}\text { Angio-ISR and } \\
\text { IVUS-ISR }\end{array}$ & $\begin{array}{l}222 \text { (colchicine } \\
\text { 112, placebo } \\
110 \text { ) }\end{array}$ & $\begin{array}{l}\text { Colchicine } \\
63.7, \\
\text { placebo } \\
63.5\end{array}$ & $\begin{array}{l}\text { Colchicine } \\
37 \text { (37.0), } \\
\text { placebo } \\
31(32.3)\end{array}$ & $\begin{array}{l}\text { Colchicine } \\
27.4, \\
\text { placebo } \\
27.5\end{array}$ & $\begin{array}{l}\text { Colchicine } \\
36(36.0), \\
\text { placebo } \\
38(40.0)\end{array}$ & $\begin{array}{l}\text { Colchicine } 48 \\
(48), \\
\text { placebo } 47 \\
(49.0)\end{array}$ \\
\hline $\begin{array}{l}\text { Nidorf } \\
\text { et al11 }\end{array}$ & Australia & CAD & $\begin{array}{l}\text { Composite } \\
\text { incidence of ACS, } \\
\text { out-of-hospital } \\
\text { cardiac arrest, } \\
\text { non-cardioembolic } \\
\text { ischemic stroke }\end{array}$ & $\begin{array}{l}532 \text { (colchicine } \\
282 \text {, placebo } \\
250 \text { ) }\end{array}$ & $\begin{array}{l}\text { Colchicine } \\
66.0, \\
\text { placebo } \\
67.0\end{array}$ & $\begin{array}{l}\text { Colchicine } \\
31(11.0) \\
\text { placebo } \\
28(11.2)\end{array}$ & NA & $\begin{array}{l}\text { Colchicine } \\
10(4.0), \\
\text { placebo } \\
14(6.0)\end{array}$ & NA \\
\hline $\begin{array}{l}\text { Akodad } \\
\text { et al }{ }^{12}\end{array}$ & France & ACS & $\begin{array}{l}\text { CRP peak } \\
\text { value during } \\
\text { hospitalization }\end{array}$ & $\begin{array}{l}44 \text { (colchicine 23, } \\
\text { placebo 21) }\end{array}$ & $\begin{array}{l}\text { Colchicine } \\
60.1, \\
\text { placebo } \\
59.7\end{array}$ & $\begin{array}{l}\text { Colchicine } \\
4(17.4), \\
\text { placebo } \\
5(23.8)\end{array}$ & NA & $\begin{array}{l}\text { Colchicine } \\
17(73.9), \\
\text { placebo } \\
14(66.7)\end{array}$ & $\begin{array}{l}\text { Colchicine } 9 \\
(39.1), \\
\text { placebo } 10 \\
(47.6)\end{array}$ \\
\hline Hennessy ${ }^{13}$ & Australia & ACS & $\begin{array}{l}\text { Residual hs-CRP } \\
\geq 2 \mathrm{mg} / \mathrm{L}\end{array}$ & $\begin{array}{l}237 \text { (colchicine } \\
119, \text { placebo } \\
118 \text { ) }\end{array}$ & $\begin{array}{l}\text { Colchicine } \\
61.0, \\
\text { placebo } \\
61.0\end{array}$ & $\begin{array}{l}\text { Colchicine } \\
30(25.2), \\
\text { placebo } \\
25(21.2)\end{array}$ & $\begin{array}{l}\text { Colchicine } \\
28.0, \\
\text { placebo } \\
28.0\end{array}$ & $\begin{array}{l}\text { Colchicine } \\
77(65.0), \\
\text { placebo } \\
67(57.0)\end{array}$ & $\begin{array}{l}\text { Colchicine } 64 \\
(54.0), \\
\text { placebo } 48 \\
(41.0)\end{array}$ \\
\hline $\begin{array}{l}\text { Tardif } \\
\text { et al }{ }^{14}\end{array}$ & $\begin{array}{c}\text { Canada } \\
\text { (multinational) }\end{array}$ & ACS & $\begin{array}{l}\text { Composite of } \\
\text { death from CV } \\
\text { causes, resuscitated } \\
\text { cardiac arrest, ACS, } \\
\text { stroke, or urgent } \\
\text { hospitalization for } \\
\text { angina leading to } \\
\text { coronary } \\
\text { revascularization }\end{array}$ & $\begin{array}{l}4,745 \text { (colchicine } \\
2,366 \text {, placebo } \\
2,379)\end{array}$ & $\begin{array}{l}\text { Colchicine } \\
60.6, \\
\text { placebo } \\
60.5\end{array}$ & $\begin{array}{l}\text { Colchicine } \\
472(19.9), \\
\text { placebo } \\
437(18.4)\end{array}$ & $\begin{array}{l}\text { Colchicine } \\
28.2 \\
\text { placebo } \\
28.4\end{array}$ & $\begin{array}{l}\text { Colchicine } \\
708(29.9), \\
\text { placebo } \\
708(29.8)\end{array}$ & $\begin{array}{l}\text { Colchicine } \\
1,185(50.1) \text {, } \\
\text { placebo } \\
1,236(52.0)\end{array}$ \\
\hline $\begin{array}{l}\text { Nidorf } \\
\text { et al15 }\end{array}$ & $\begin{array}{l}\text { Australia and } \\
\text { Netherlands }\end{array}$ & CAD & $\begin{array}{l}\text { Composite of CV } \\
\text { death, ACS, } \\
\text { ischemic stroke, or } \\
\text { ischemia-driven } \\
\text { coronary } \\
\text { revascularization }\end{array}$ & $\begin{array}{l}5,522 \text { (colchicine } \\
2,762 \text {, placebo } \\
2,760 \text { ) }\end{array}$ & $\begin{array}{l}\text { Colchicine } \\
65.8, \\
\text { placebo } \\
65.9\end{array}$ & $\begin{array}{l}\text { Colchicine } \\
457 \text { (16.5), } \\
\text { placebo } \\
389(14.1)\end{array}$ & NA & $\begin{array}{l}\text { Colchicine } \\
318(11.5), \\
\text { placebo } \\
330(12.0)\end{array}$ & $\begin{array}{l}\text { Colchicine } \\
1,421(51.4) \text {, } \\
\text { placebo } \\
1,387(50.3)\end{array}$ \\
\hline $\begin{array}{l}\text { Tong } \\
\text { et al }{ }^{16}\end{array}$ & Australia & CAD & $\begin{array}{l}\text { Composite of all- } \\
\text { cause mortality, } \\
\text { ACS, ischemia- } \\
\text { driven urgent } \\
\text { revascularization, } \\
\text { and non- } \\
\text { cardioembolic } \\
\text { ischemic stroke }\end{array}$ & $\begin{array}{l}795 \text { (colchicine } \\
\text { 396, placebo } \\
\text { 399) }\end{array}$ & $\begin{array}{l}\text { Colchicine } \\
59.7 \text {, } \\
\text { placebo } \\
60.0\end{array}$ & $\begin{array}{l}\text { Colchicine } \\
74(18.7), \\
\text { placebo } \\
89(22.3)\end{array}$ & NA & $\begin{array}{l}\text { Colchicine } \\
128(32), \\
\text { placebo } \\
149(37)\end{array}$ & $\begin{array}{l}\text { Colchicine } \\
201(51), \\
\text { placebo } 199 \\
(50)\end{array}$ \\
\hline
\end{tabular}

Unless indicated otherwise, data show the number of patients with percentages in parentheses. ${ }^{A} 35$ patients with ACS and 5 patients with AIS. B38 patients with ACS and 2 patients with AIS. ACS, acute coronary syndrome; AIS, acute ischemic stroke; BMI, body mass index; CABG, coronary artery bypass grafting; CAD, coronary artery disease; CRP, C-reactive protein; CV, cardiovascular; hs-CRP, high-sensitivity C-reactive protein; ISR, in-stent restenosis; IVUS, intravascular ultrasound; NA, not applicable; PCI, percutaneous coronary intervention; TIA, transient ischemic attack.

(Table 1 continued the next page.)

\section{(Reference CRD42020178878).}

\section{Search Methods}

We first searched for relevant material in March 2020 in the MEDLINE, Cochrane Central Register of Controlled Trials (CENTRAL), PsycINFO, Web of Science Core Collection, SciELO Citation Index, Korean Journal Database, and the Russian Science Citation Index databases. The search was updated in January 2021.

The search methods used are summarized in Supplementary
Data 1. In addition, we analyzed the references presented in the included studies and review articles to extract significant data.

\section{Study Selection Criteria and Outcomes}

We selected all available RCTs whose patients presented with CAD, including acute coronary syndrome (ACS) or myocardial infarction (MI) and chronic coronary syndrome or stable coronary disease, regardless of the presence of other comorbidities (including other atherosclerotic 


\begin{tabular}{|c|c|c|c|c|c|c|c|c|c|c|}
\hline Reference & Diabetes & $\begin{array}{c}\text { Hyperlip- } \\
\text { idemia }\end{array}$ & $\begin{array}{l}\text { History } \\
\text { of angina } \\
\text { or MI }\end{array}$ & $\begin{array}{l}\text { History } \\
\text { of PCl }\end{array}$ & $\begin{array}{l}\text { History } \\
\text { of CABG }\end{array}$ & $\begin{array}{c}\text { History } \\
\text { of heart } \\
\text { failure }\end{array}$ & $\begin{array}{l}\text { History } \\
\text { of stroke } \\
\text { or TIA }\end{array}$ & $\begin{array}{c}\text { Colchicine } \\
\text { intervention }\end{array}$ & Control & $\begin{array}{l}\text { Follow-up } \\
\text { (months) }\end{array}$ \\
\hline $\begin{array}{l}\text { O'Keefe } \\
\text { et al9 }\end{array}$ & $\begin{array}{l}\text { Colchicine } \\
16(12.0), \\
\text { placebo } \\
8(12.0)\end{array}$ & NA & $\begin{array}{l}\text { Colchicine } \\
52(40.0), \\
\text { placebo } \\
26(39.0)\end{array}$ & NA & $\begin{array}{l}\text { Colchicine } \\
34(26.0), \\
\text { placebo } \\
17(25.0)\end{array}$ & NA & NA & $0.6 \mathrm{mg}$, b.i.d. & Placebo & 6 \\
\hline $\begin{array}{l}\text { Raju } \\
\text { et al10 }\end{array}$ & $\begin{array}{l}\text { Colchicine } \\
7(17.5), \\
\text { placebo } \\
6(15.0)\end{array}$ & $\begin{array}{l}\text { Colchicine } \\
19(47.5), \\
\text { placebo } \\
19(47.5)\end{array}$ & $\begin{array}{l}\text { Colchicine } \\
8(20.0), \\
\text { placebo } \\
6(15.0)\end{array}$ & NA & NA & $\begin{array}{l}\text { Colchicine } \\
1(2.5), \\
\text { placebo } \\
0(0.0)\end{array}$ & $\begin{array}{l}\text { Colchicine } \\
3(7.5), \\
\text { placebo } \\
0(0)\end{array}$ & $1 \mathrm{mg} /$ day & Placebo & 1 \\
\hline $\begin{array}{l}\text { Deftereos } \\
\text { et }\left.a\right|^{3}\end{array}$ & $\begin{array}{l}\text { Colchicine } \\
100(100), \\
\text { placebo } \\
96(100)\end{array}$ & NA & NA & NA & NA & NA & NA & $0.5 \mathrm{mg}$, b.i.d. & Placebo & 6 \\
\hline $\begin{array}{l}\text { Nidorf } \\
\text { et al11 }\end{array}$ & $\begin{array}{l}\text { Colchicine } \\
92(33.0), \\
\text { placebo } \\
69(28.0)\end{array}$ & NA & $\begin{array}{l}\text { Colchicine } \\
64(23.0), \\
\text { placebo } \\
61(24.0)\end{array}$ & $\begin{array}{l}\text { Colchicine } \\
169(60.0), \\
\text { placebo } \\
138(55.0)\end{array}$ & $\begin{array}{l}\text { Colchicine } \\
62(22.0), \\
\text { placebo } \\
39(16.0)\end{array}$ & NA & NA & $0.5 \mathrm{mg} / \mathrm{day}$ & No colchicine & 36 \\
\hline $\begin{array}{l}\text { Akodad } \\
\text { et } \mathrm{al}^{12}\end{array}$ & $\begin{array}{l}\text { Colchicine } \\
3(13.0) \\
\text { placebo } \\
3(14.3)\end{array}$ & $\begin{array}{l}\text { Colchicine } \\
8 \text { (34.8), } \\
\text { placebo } \\
8(38.1)\end{array}$ & NA & $\begin{array}{l}\text { Colchicine } \\
1(4.3), \\
\text { placebo } \\
1(4.8)\end{array}$ & $\begin{array}{l}\text { Colchicine } \\
0(0.0) \\
\text { placebo } \\
1(4.8)\end{array}$ & NA & NA & $1 \mathrm{mg} /$ day & No colchicine & 1 \\
\hline Hennessy ${ }^{13}$ & $\begin{array}{l}\text { Colchicine } \\
27(23.0), \\
\text { placebo } \\
25(21.0)\end{array}$ & NA & $\begin{array}{l}\text { Colchicine } \\
18(15.0), \\
\text { placebo } \\
18(15.0)\end{array}$ & $\begin{array}{l}\text { Colchicine } 13 \\
\text { placebo } 14\end{array}$ & $\begin{array}{l}3(11.0), \\
12.0)\end{array}$ & NA & NA & $0.5 \mathrm{mg} / \mathrm{day}$ & Placebo & 1 \\
\hline $\begin{array}{l}\text { Tardif } \\
\text { et al }\left.\right|^{14}\end{array}$ & $\begin{array}{l}\text { Colchicine } \\
462(19.5), \\
\text { placebo } \\
497(20.9)\end{array}$ & NA & $\begin{array}{l}\text { Colchicine } \\
370(15.6), \\
\text { placebo } \\
397(16.7)\end{array}$ & $\begin{array}{l}\text { Colchicine } \\
392(16.6), \\
\text { placebo } \\
406(17.1)\end{array}$ & $\begin{array}{l}\text { Colchicine } \\
69(2.9), \\
\text { placebo } \\
81(3.4)\end{array}$ & $\begin{array}{l}\text { Colchicine } \\
48(2.0), \\
\text { placebo } \\
42(1.8)\end{array}$ & $\begin{array}{l}\text { Colchicine } \\
55(2.3), \\
\text { placebo } \\
67(2.8)\end{array}$ & $0.5 \mathrm{mg} / \mathrm{day}$ & Placebo & 22.6 \\
\hline $\begin{array}{l}\text { Nidorf } \\
\text { et al'15 }\end{array}$ & $\begin{array}{l}\text { Colchicine } \\
632(22.9), \\
\text { placebo } \\
662(24.0)\end{array}$ & NA & $\begin{array}{l}\text { Colchicine } \\
2,323 \\
(84.1) \\
\text { placebo } \\
2,335(84.6)\end{array}$ & $\begin{array}{l}\text { Colchicine } \\
2,100 \\
(76.0) \\
\text { placebo } \\
2,077(75.3)\end{array}$ & $\begin{array}{l}\text { Colchicine } \\
319 \\
(11.5), \\
\text { placebo } \\
391(14.2)\end{array}$ & NA & NA & $0.5 \mathrm{mg} / \mathrm{day}$ & Placebo & 28.6 \\
\hline $\begin{array}{l}\text { Tong } \\
\text { et al }{ }^{16}\end{array}$ & $\begin{array}{l}\text { Colchicine } \\
75(19.0), \\
\text { placebo } \\
76(19.0)\end{array}$ & $\begin{array}{l}\text { Colchicine } \\
180(46.0), \\
\text { placebo } \\
185(46.0)\end{array}$ & $\begin{array}{l}\text { Colchicine } \\
59(15.0), \\
\text { placebo } \\
59(15.0)\end{array}$ & $\begin{array}{l}\text { Colchicine } \\
51(13.0), \\
\text { placebo } \\
50(13.0)\end{array}$ & $\begin{array}{l}\text { Colchicine } \\
15(4.0) \\
\text { placebo } \\
19(5.0)\end{array}$ & NA & $\begin{array}{l}\text { Colchicine } \\
5(1.0), \\
\text { placebo } \\
11(3.0)\end{array}$ & $\begin{array}{l}0.5 \mathrm{mg} \text {, b.i.d. } \\
\text { for } 1 \mathrm{month} \text {, } \\
\text { then } 0.5 \mathrm{mg} / \\
\text { day for } 11 \\
\text { months }\end{array}$ & Placebo & 12 \\
\hline
\end{tabular}

or ischemic events). These studies had to include a lowdose colchicine $(\leq 1.5 \mathrm{mg} / \mathrm{day})$ arm and a control group (placebo, standard treatment, or other alternative treatment). We did not exclude studies with cointerventions if they were administered to both groups of the study. In randomized cross-over trials, only the first stage was considered. We defined a minimum follow-up period of 1 month. To broadly evaluate the clinical impact of colchicine, we considered cardiovascular mortality and major adverse cardiovascular events (MACE) as the primary outcomes. Different definitions of MACE were considered. Secondary outcomes were MI, stroke, heart failure, hospitalization (all causes), cardiovascular interventions (e.g., urgent revascularization), and adverse events, namely gas- trointestinal adverse events.

\section{Data Extraction}

The titles and abstracts yielded by the searches against the inclusion criteria were first screened by 2 independent reviewers (A.M.A., B.N.-G.). In the second stage, the reviewers read the full-text reports and determined whether the studies met the inclusion criteria. The reasons for the exclusion of articles were recorded at both screening stages. Disagreements were resolved by consensus or with the help of a third reviewer (D.C.). Regarding the same study, the most recent data were considered.

The reviewers (A.M.A., B.N.-G.) then extracted data from the individual studies identified for inclusion into a 


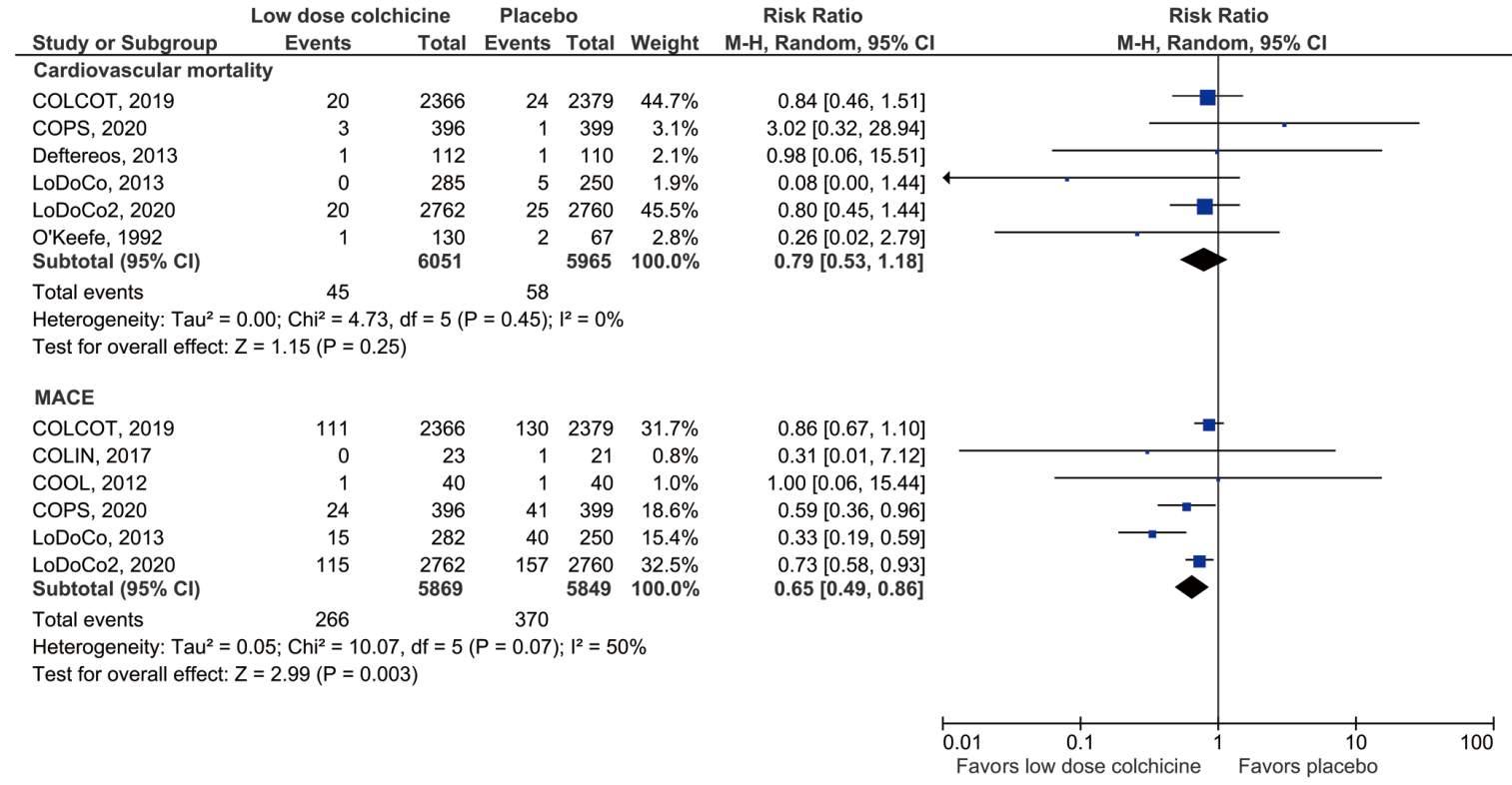

Figure 1. Forest plot: cardiovascular mortality and major adverse cardiovascular events (MACE). Cl, confidence interval.

pre-piloted form that included information about the description of the intervention and controls, population characteristics, outcome measurements, statistical data, and results.

\section{Data Evaluation, Synthesis, and Analysis}

The risk of bias in the included studies was assessed using Cochrane risk of bias tool. ${ }^{7}$ This tool evaluates random sequence generation, allocation concealment, selective reporting, blinding of participants and personnel, blinding of outcome assessment, and incomplete outcome data. The criteria were applied by 2 independent reviewers (A.M.A., B.N.-G.) and disagreements were resolved by consensus or with the help of another 2 reviewers (M.A., D.C.).

A meta-analysis of the data retrieved from the included studies was conducted using RevMan version 5.3 (The Nordic Cochrane Centre, Copenhagen, Denmark; The Cochrane Collaboration, 2014; https://training.cochrane. org/online-learning/core-software-cochrane-reviews/ revman/revman-5-download).

Statistical heterogeneity was used to define the method of analysis. Heterogeneity was determined through $\mathrm{I}^{2}$ statistics and deemed to be substantial if greater than $50 \%$. This index reflects the percentage of total variation among studies that is due to heterogeneity rather than random. The DerSimonian and Laird random effects model was used. Publication bias was assessed through examinations of funnel plots if more than 10 studies were included.

\section{Assessment of Confidence in the Cumulative Evidence}

The evaluation of primary outcomes was performed using the Grading of Recommendations Assessment, Development and Evaluation (GRADE) framework regarding the risk of bias, imprecision, inconsistency, indirectness, and publication bias. ${ }^{\mathbf{8}}$ The pooled evidence was then classified as having very low, low, moderate, or high confidence.

\section{Results}

\section{Included Studies}

The search yielded 314 articles. From those, 194 were excluded after screening the titles and abstracts. From the remaining 118 articles subjected to full-text assessment, 9 met the inclusion criteria.,9-16 The reasons for exclusion are detailed in Supplementary Data 2.

From the 9 RCTs included in this study (Table 1), 4 involved patients with ACS or $\mathrm{MI}^{10,12-14}$ and 5 included patients with chronic coronary syndrome or stable coronary disease. ${ }^{3,9,11,15,16}$ One study enrolled patients with acute ischemic stroke in addition to patients with ACS. ${ }^{10}$

The eligible studies included 12,374 patients, 5,894 with ACS, 6,473 with chronic coronary syndrome, and 7 with acute ischemic stroke. The median age of the participants ranged between 57.2 and 67.0 years. All eligible studies enrolled a total of $1,130(9.1 \%)$ women in the colchicine group and 1,016 (8.2\%) in the placebo/no colchicine group. In all studies, patients were followed-up for a median period of 12.7 months. Seven studies compared colchicine treatment with placebo ${ }^{3,9,10,13-16}$ and 2 studies compared colchicine with standard treatment alone.11,12 A summary of the main characteristics of the studies, including cardiovascular risk factors, is presented in Table $\mathbf{1 .}$

\section{Risk of Bias}

Regarding the risk of bias, the Colchicine Cardiovascular Outcomes Trial (COLCOT), ${ }^{14}$ Colchicine in Patients with Acute Coronary Syndrome (COPS), ${ }^{16}$ and Low Dose Colchicine for Secondary Prevention of Cardiovascular Disease 2 (LoDoCo2) ${ }^{\mathbf{1 5}}$ trials were classified as having a low risk of bias in all domains, whereas the LoDoCo-MI'13 trial and the trial by $\mathrm{O}^{\prime}$ Keefe et $\mathrm{al}^{9}$ revealed some concerns, especially due to a lack of information about the randomization and blinding process. Four trials exhibited a high 


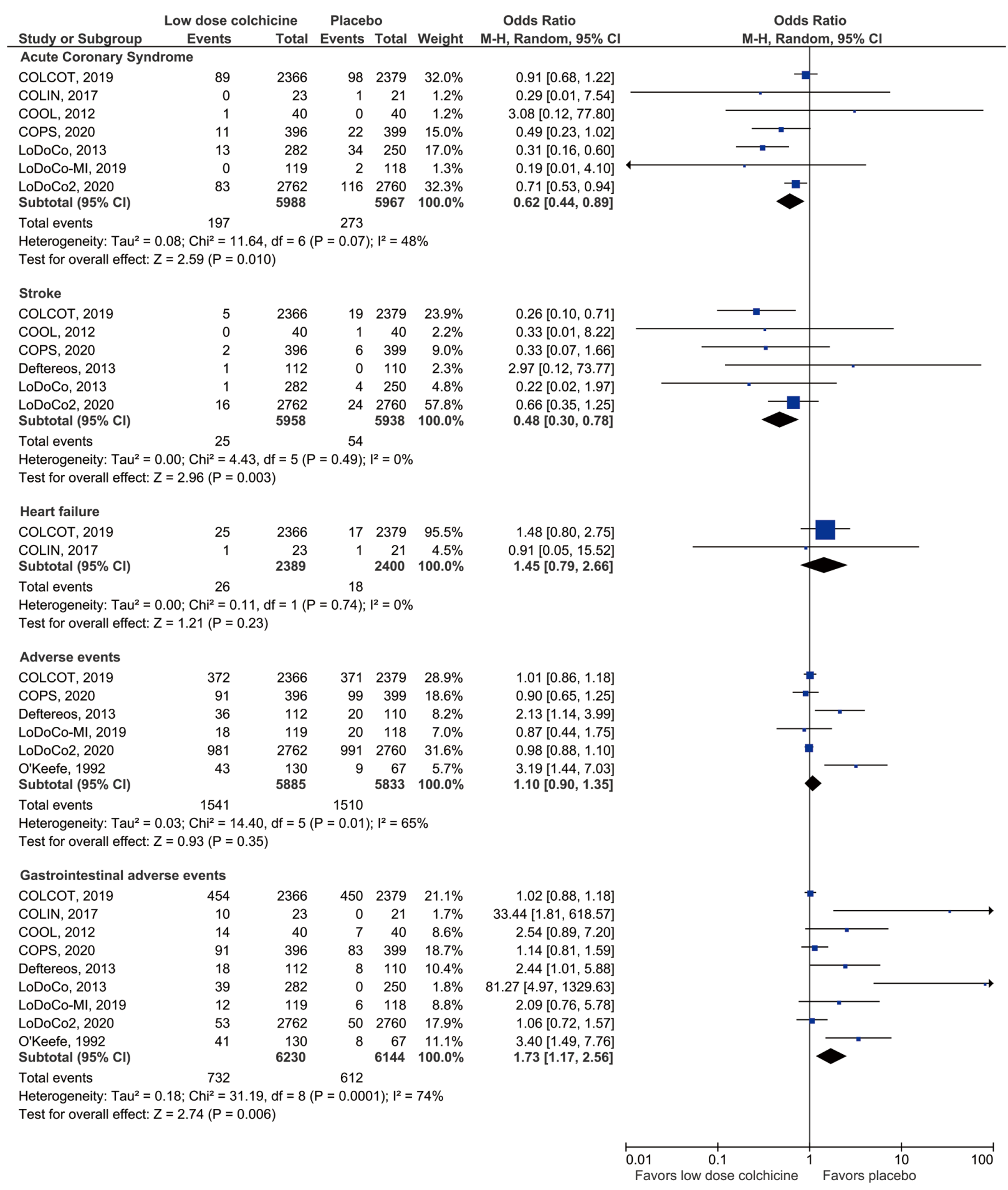

Figure 2. Forest plot: acute coronary syndrome, stroke, heart failure, adverse events, and gastrointestinal adverse events. Cl, confidence interval.

overall risk of bias.,10-12 Detailed information about the risk of bias is provided in Supplementary Data 3.

Primary Outcomes: Cardiovascular Mortality and MACE Pooled data (Figure 1) showed no difference in cardiovas- cular mortality (risk ratio [RR] 0.79; $95 \%$ confidence interval $[\mathrm{CI}] 0.53-1.18 ; 6 \mathrm{RCTs} ; \mathrm{I}^{2}=0 \% ; 12,016$ patients), but low-dose colchicine was associated with a significant risk reduction in MACE (RR 0.65; 95\% CI 0.49-0.86; 6 RCTs; $\mathrm{I}^{2}=50 \% ; 11,718$ patients). 


\begin{tabular}{|c|c|c|c|c|c|c|c|}
\hline \multirow[b]{2}{*}{ Outcome } & \multirow[b]{2}{*}{$\begin{array}{l}\text { No. } \\
\text { participants } \\
\text { (studies) }\end{array}$} & \multirow[b]{2}{*}{$\begin{array}{c}\text { RR } \\
(95 \% \mathrm{Cl})\end{array}$} & \multicolumn{3}{|c|}{ Anticipated absolute effects $(95 \% \mathrm{Cl})$} & \multirow[b]{2}{*}{ Certainty } & \multirow[b]{2}{*}{ What happens } \\
\hline & & & $\begin{array}{l}\text { Without } \\
\text { colchicine } \\
(\%)\end{array}$ & $\begin{array}{c}\text { With } \\
\text { colchicine } \\
(\%)\end{array}$ & $\begin{array}{l}\text { Difference }^{A} \\
(\%)\end{array}$ & & \\
\hline CV mortality & $\begin{array}{l}12,016 \\
\text { (6 RCTs) }\end{array}$ & $\begin{array}{c}0.79 \\
(0.53,1.18)\end{array}$ & 1.0 & $\begin{array}{c}0.8 \\
(0.5,1.1)\end{array}$ & $\begin{array}{c}-0.2 \\
(-0.5,0.2)\end{array}$ & $\oplus \oplus \oplus \bigcirc$ Moderate ${ }^{B}$ & $\begin{array}{l}\text { Colchicine likely reduces } \\
\text { CV mortality slightly }\end{array}$ \\
\hline MACE & $\begin{array}{l}111,718 \\
\text { (6 RCTs) }\end{array}$ & $\begin{array}{c}0.65 \\
(0.49,0.86)\end{array}$ & 6.3 & $\begin{array}{c}4.1 \\
(3.1,5.4)\end{array}$ & $\begin{array}{c}-2.2 \\
(-3.2,-0.9)\end{array}$ & $\oplus \oplus \oplus \bigcirc$ Moderate $\mathrm{C}$ & $\begin{array}{l}\text { Colchicine likely reduces } \\
\text { MACE }\end{array}$ \\
\hline ACS & $\begin{array}{c}11,955 \\
\text { (7 RCTs) }\end{array}$ & $\begin{array}{c}0.64 \\
(0.46,0.90)\end{array}$ & 4.6 & $\begin{array}{c}2.9 \\
(2.1,4.1)\end{array}$ & $\begin{array}{c}-1.6 \\
(-2.5,-0.5)\end{array}$ & $\oplus \bigcirc \bigcirc \bigcirc$ Very low $\mathrm{C}, \mathrm{D}$ & $\begin{array}{l}\text { Colchicine may reduce } \\
\text { ACS, but the evidence is } \\
\text { very uncertain }\end{array}$ \\
\hline Stroke & $\begin{array}{l}11,896 \\
\text { (6 RCTs) }\end{array}$ & $\begin{array}{c}0.49 \\
(0.30,0.78)\end{array}$ & 0.9 & $\begin{array}{c}0.4 \\
(0.3,0.7)\end{array}$ & $\begin{array}{c}-0.5 \\
(-0.6,-0.2)\end{array}$ & $\oplus \oplus \oplus \bigcirc$ Moderate $\mathrm{E}$ & $\begin{array}{l}\text { Colchicine likely results in } \\
\text { a reduction in stroke }\end{array}$ \\
\hline Heart failure & $\begin{array}{c}4,789 \\
\text { (2 RCTs) }\end{array}$ & $\begin{array}{c}1.44 \\
(0.79,2.63)\end{array}$ & 0.8 & $\begin{array}{c}1.1 \\
(0.6,2)\end{array}$ & $\begin{array}{c}0.3 \\
(-0.2,1.2)\end{array}$ & $\oplus \bigcirc \bigcirc \bigcirc$ Very low $\mathrm{B}, \mathrm{F}, \mathrm{G}$ & $\begin{array}{l}\text { Colchicine may have little } \\
\text { to no effect on heart } \\
\text { failure, but the evidence } \\
\text { is very uncertain }\end{array}$ \\
\hline Hospitalizations & $\begin{array}{l}11,299 \\
\text { (4 RCTs) }\end{array}$ & $\begin{array}{c}0.76 \\
(0.53,1.10)\end{array}$ & 5.9 & $\begin{array}{c}4.4 \\
(3.1,6.4)\end{array}$ & $\begin{array}{c}-1.4 \\
(-2.8,0.6)\end{array}$ & $\oplus \bigcirc \bigcirc \bigcirc$ Very low $\mathrm{B}, \mathrm{C}$ & $\begin{array}{l}\text { Colchicine may reduce or } \\
\text { have little to no effect on } \\
\text { hospitalizations, but the } \\
\text { evidence is very uncertain }\end{array}$ \\
\hline CV interventions & $\begin{array}{c}11,284 \\
\text { (4 RCTs) }\end{array}$ & $\begin{array}{c}0.61 \\
(0.42,0.89)\end{array}$ & 4.3 & $\begin{array}{c}2.6 \\
(1.8,3.8)\end{array}$ & $\begin{array}{c}-1.7 \\
(-2.5,-0.5)\end{array}$ & $\oplus \oplus \oplus \oplus$ High & $\begin{array}{l}\text { Colchicine results in large } \\
\text { reductions in CV } \\
\text { interventions }\end{array}$ \\
\hline AEs & $\begin{array}{c}11,718 \\
\text { (6 RCTs) }\end{array}$ & $\begin{array}{c}1.07 \\
(0.92,1.25)\end{array}$ & 25.9 & $\begin{array}{c}27.7 \\
(23.8,32.4)\end{array}$ & $\begin{array}{c}1.8 \\
(-2.1,6.5)\end{array}$ & $\oplus \bigcirc \bigcirc \bigcirc$ Very low $\mathrm{B}, \mathrm{C}, \mathrm{H}$ & $\begin{array}{l}\text { Colchicine may increase } \\
\text { or have little to no effect } \\
\text { on AEs, but the evidence } \\
\text { is very uncertain }\end{array}$ \\
\hline Gl events & $\begin{array}{c}12,374 \\
\text { (9 RCTs) }\end{array}$ & $\begin{array}{c}1.54 \\
(1.11,2.13)\end{array}$ & 10.0 & $\begin{array}{c}15.3 \\
(11.1,21.2)\end{array}$ & $\begin{array}{c}5.4 \\
(1.1,11.3)\end{array}$ & $\oplus \circ \bigcirc \bigcirc$ Very low $\mathrm{c}, \mathrm{I}$ & $\begin{array}{l}\text { Colchicine may increase or } \\
\text { have little to no effect on GI } \\
\text { events, but the evidence is } \\
\text { very uncertain }\end{array}$ \\
\hline
\end{tabular}

ANegative values indicate fewer events, positive values indicate more events. BThe relative effect has a $95 \%$ confidence interval $(\mathrm{Cl})$ that includes 1 , which is not statistically significant. CThis outcome has significant heterogeneity $\left(I^{2} \geq 50 \%\right)$ or a Chi-squared test with $P<0.10$. $D$ The risk of bias assessment of the studies that report acute coronary syndrome (ACS) includes 3 studies with high risk and 1 with moderate risk (some concerns). EThe risk of bias assessment of the studies that report stroke events includes 3 studies with high risk and 3 with low risk. FThe risk of bias assessment of the studies that report heart failure events includes 1 study with high risk and 1 with low risk. GOnly 2 studies were available for this outcome. HThe risk of bias assessment of the studies that report adverse effects includes 2 studies with high risk, 2 with moderate risk (some concerns), and 3 with low risk. 'The risk of bias assessment of the studies that report gastrointestinal (Gl) events includes 4 studies with high risk and 2 with moderate risk (some concerns). The risk in the intervention group (and its $95 \% \mathrm{Cl}$ ) is based on the assumed risk in the comparison group and the relative effect of the intervention (and its $95 \% \mathrm{Cl}$ ). Certainty graded from very low $(\oplus \circ 0 \bigcirc)$ to high $(\oplus \oplus \oplus \oplus)$. AEs, adverse events; CV, cardiovascular; MACE, major adverse cardiac events; RCTs, randomized controlled trials; RR, risk ratio.

\section{Secondary Outcomes}

Colchicine administration was associated with a $36 \%$ risk reduction in ACS (RR 0.64; 95\% CI 0.46-0.90; $\mathrm{I}^{2}=47 \% ; 7$ $\mathrm{RCTs} ; 11,955$ patients) and a $51 \%$ risk reduction in stroke events (RR 0.49; 95\% CI 0.30-0.78; I2=0\%; 6 RCTs; 11.896 patients; Figure 2). The LoDoCo $2^{15}$ and COLCOT ${ }^{14}$ trials were the major contributors to these outcomes.

Heart failure events (RR 1.44; 95\% CI 0.79-2.63; I $\mathrm{I}^{2}=0 \%$; 2 RCTs; 4,789 patients; Figure 2) and hospitalizations (RR 0.76; 95\% CI 0.53-1.10; I ${ }^{2}=52 \%$; 4 RCTs; 11,299 patients) did not differ among the groups (Supplementary Data 4).

Urgent coronary revascularizations were also significantly reduced by colchicine administration (RR $0.61 ; 95 \% \mathrm{CI}$ $0.42-0.89 ; \mathrm{I}^{2}=40 \%$; 4 RCTs; 11,284 patients; Supplementary Data 4).

Overall adverse events (RR 1.07; 95\% CI 0.92-1.25; $\mathrm{I}^{2}=62 \%$; 6 RCTs; 11,718 patients) did not differ between the 2 arms, but colchicine significantly increased gastrointestinal events (RR 1.54; 95\% CI 1.11-2.13; I ${ }^{2}=72 \% ; 9$ RCTs; 12,374 patients; Figure 2).

\section{Subgroup Analysis}

Subgroup analysis with different follow-up periods was performed (Supplementary Data 5). There were no differences in the main outcomes between the 2 groups. There was a significant difference in the rate of hospitalization with a shorter follow-up period, but only 1 study was included in this subgroup analysis. The rate of gastrointestinal adverse events also differed between subgroups: studies with a longer follow-up period had a lower RR than those with a shorter follow-up period, but heterogeneity was high $\left(\mathrm{I}^{2}=71 \%\right)$.

\section{Assessment of Confidence in the Cumulative Evidence}

Table 2 presents a summary of the findings regarding the certainty of the evidence (GRADE). Although most outcomes exhibited very low certainty, cardiovascular mortality, MACE, and stroke outcomes were of moderate certainty and cardiovascular intervention outcomes had high certainty.

\section{Discussion}

This systematic review showed that low-dose colchicine in patients with CAD is associated with a $35 \%$ risk reduction of MACE, a $36 \%$ risk reduction of ACS, a $51 \%$ risk reduc- 
tion of stroke, and a 39\% risk reduction of cardiovascular interventions. However, there was no significant risk reduction in cardiovascular mortality, heart failure events, or hospitalizations. As expected, the risk of gastrointestinal events was increased with colchicine, but overall adverse events were not different among the groups.

Colchicine has a well-documented therapeutic use in inflammatory conditions, and so a potential benefit of colchicine in patients with coronary and cerebrovascular disease has been previously hypothesized. Colchicine is a classical antimitotic drug, the primary mechanism of action of which is tubulin disruption. This leads to downregulation of multiple inflammatory pathways and modulates innate immunity. Newly described mechanisms of action of colchicine include blocking the activity of the NLRP3 (NOD-, LRR- and pyrin domain-containing protein 3) inflammasome, with suppression of interleukin (IL)-1 $\beta$ and IL-18 release. ${ }^{17,18}$ NLR3 inflammasomes are activated by cholesterol crystals that form early in disease, leading to the secretion of active proinflammatory Type 1 cytokines IL- $1 \beta$ and IL-18. Both IL- $1 \beta$ and IL-18 have been associated with plaque formation, progression, and rupture. ${ }^{18}$ In fact, blockade of the IL-1 $\beta$ pathway was recently shown in the Canakinumab Antiinflammatory Thrombosis Outcome Study (CANTOS) study to effectively reduce cardiovascular events. ${ }^{19}$ That randomized double blind placebo-controlled trial included more than 10,000 patients with a history of $\mathrm{MI}$ and a persistent proinflammatory response, defined as a high-sensitivity C-reactive protein concentration of $\geq 2 \mathrm{mg} / \mathrm{L}$, and showed that treatment with canakinumab, a monoclonal antibody targeting IL- $1 \beta$, led to a $15 \%$ lower risk of cardiovascular events, independent of decreases in lipid levels. ${ }^{19}$

One of the major findings of the present study was an important reduction in the risk of stroke with colchicine use. One possible reason for this is related to the possible prevention of atrial fibrillation and the consequent reduction in cardioembolic stroke, as observed in studies using colchicine in patients undergoing cardiac surgery. ${ }^{20}$ Despite the fact that we could not discriminated between stroke subtypes using the available data, it seems reasonable to assume that the reduction in stroke risk may include not only cardioembolic stroke, but also atherosclerotic stroke.

The putative benefits of colchicine have been not only in RCTs, but also in earlier observational studies enrolling patients with gout, which indicated that colchicine use was associated with a reduced risk of cardiovascular events. ${ }^{21}$

Together, both RCTs (pooled in our systematic review) and observational data support a beneficial effect of colchicine use in patients with CAD. Furthermore this seems to be a cost-effective intervention in patients who experience an ACS. ${ }^{22}$

In clinical practice, gastrointestinal adverse events are expected to occur with the use of colchicine, mainly diarrhea, nausea, and vomiting, all of which are generally mild in severity.

\section{Study Limitations}

There are some study limitations to consider regarding the results and conclusions of the analysis. All trials have their own limitations, and pooling them together using their meta-data limits the robustness of data interpretation. Across studies, because of the allowed broad spectrum of cardiovascular diseases, the baseline conditions could differ. In addition, a study was included in which there was a negligible proportion of patients with acute ischemic stroke, ${ }^{10}$ although we are confident that this did not interfere with the main results. Most studies enrolled a modest number of participants, and some of the outcomes were only reported by few studies, making it difficult to identify clinical differences for each outcome. In addition, women constituted a minor proportion of the population included, probably due to a higher percentage of CAD in men. However, this unequal sex representation limits data extrapolation to women.

Another study limitation concerns the different definitions used for MACE, heart failure, and hospitalizations, which could limit the interpretation of the results and possible assumptions (Supplementary Data 6).

\section{Conclusions}

The use of low-dose colchicine in patients with CAD seems to be associated with a significant risk reduction in MACE, ACS, stroke, and cardiovascular interventions. However, there is an increased risk of gastrointestinal events, which should be expected in treated patients.

\section{Authors Contributions}

A.M.A. and D.C. created the concept and wrote the first draft of the manuscript. A.M.A., B.N.-G. and D.C. were responsible for data acquisition and extraction. All the authors contributed to data analysis, interpretation, draft revision and approved the final version of the submitted manuscript. D.C. is the guarantor.

\section{Sources of Funding}

This research did not receive any specific grant from funding agencies in the public, commercial, or not-for-profit sectors.

\section{Disclosures}

M.A. has participated in conferences with Boehringer-Ingelheim, AstraZeneca, Bayer, Bristol Myers Squibb Grünenthal, Tecnimede, and Merck Sharp \& Dohme. D.B. reports personal fees from lectures or participation in advisory boards from Amgen, AstraZeneca, Boehringer-Ingelheim, Novartis, Pfizer, Roche Diagnostics, Servier and Vifor Pharma, all outside the submitted work. F.J.P. has received consultant and speaker fees from AstraZeneca, Bayer, BMS, Boehringer-Ingelheim, and Daiichi Sankyo. D.C. has participated in educational meetings and/or attended conferences or symposia (including travel, accommodation) with Daiichi Sankyo, Menarini, Merck Serono and Roche in the past 3 years.

\section{IRB Information}

This study was granted an exemption from requiring ethics approval from an ethics committee because the study was a systematic review with meta-analysis.

\section{References}

1. Cui H, Miao S, Esworthy T, Zhou X, Lee S, Liu C, et al. 3D bioprinting for cardiovascular regeneration and pharmacology. Adv Drug Deliv Rev 2018; 132: 252-269.

2. Costa J, Alarcão J, Araujo F, Ascenção R, Caldeira D, Fiorentino $\mathrm{F}$, et al. The burden of atherosclerosis in Portugal. Eur Heart $J$ Qual Care Clin Outcomes 2021; 7: 154-162.

3. Deftereos S, Giannopoulos G, Raisakis K, Kossyvakis C, Kaoukis A, Panagopoulou V, et al. Colchicine treatment for the prevention of bare-metal stent restenosis in diabetic patients. $J$ Am Coll Cardiol 2013; 61: 1679-1685.

4. Terkeltaub RA. Colchicine update: 2008. Semin Arthritis Rheum 2009; 38: 411-419.

5. Deftereos S. Colchicine and the heart: Pushing the envelope. $J$ Am Coll Cardiol 2013; 62: 1817-1825.

6. Liberati A, Altman DG, Tetzlaff J, Mulrow C, Gotzsche PC, Ioannidis JPA, et al. The PRISMA statement for reporting sys- 
tematic reviews and meta-analyses of studies that evaluate healthcare interventions: Explanation and elaboration. $B M J$ 2009; 339: b2700-b2700.

7. Higgins JP, Green S, editors. Cochrane handbook for systematic reviews of interventions. Chichester: John Wiley \& Sons; 2008.

8. Atkins D, Best D, Briss PA, Eccles M, Falck-Ytter Y, Flottorp $\mathrm{S}$, et al. Grading quality of evidence and strength of recommendations. BMJ 2004; 328: 1490.

9. O'Keefe JH Jr, McCallister BD, Bateman TM, Kuhnlein DL, Ligon RW, Hartzler GO. Ineffectiveness of colchicine for the prevention of restenosis after coronary angioplasty. $\mathrm{J} \mathrm{Am} \mathrm{Coll}$ Cardiol 1992; 19: 1597-1600.

10. Raju NC, Yi Q, Nidorf M, Fagel ND, Hiralal R, Eikelboom JW. Effect of colchicine compared with placebo on high sensitivity C-reactive protein in patients with acute coronary syndrome or acute stroke: A pilot randomized controlled trial. J Thromb Thrombolysis 2012; 33: 88-94.

11. Nidorf SM, Eikelboom JW, Budgeon CA, Thompson PL. Lowdose colchicine for secondary prevention of cardiovascular disease. J Am Coll Cardiol 2013; 61: 404-410.

12. Akodad M, Lattuca B, Nagot N, Georgescu V, Buisson M, Cristol JP, et al. COLIN trial: Value of colchicine in the treatment of patients with acute myocardial infarction and inflammatory response. Arch Cardiovasc Dis 2017; 110: 395-402.

13. Hennessy T. The Low Dose Colchicine after Myocardial Infarction (LoDoCo-MI) study: A pilot randomized placebo controlled trial of colchicine following acute myocardial infarction. Am Heart J 2019; 215: 62-69.

14. Tardif JC, Kouz S, Waters DD, Bertrand OF, Diaz R, Maggioni $\mathrm{AP}$, et al. Efficacy and safety of low-dose colchicine after myocardial infarction. $N$ Engl J Med 2019; 381: 2497-2505.

15. Nidorf SM, Fiolet ATL, Mosterd A, Eikelboom JW, Schut A, Opstal TSJ, et al. Colchicine in patients with chronic coronary disease. $N$ Engl J Med 2020; 383: 1838-1847.

16. Tong DC, Quinn S, Nasis A, Hiew C, Roberts-Thomson P, Adams $\mathrm{H}$, et al. Colchicine in patients with acute coronary syndrome: The Australian COPS randomized clinical trial. Circulation 2020; 142: 1890-1900.

17. Leung YY, Yao Hui LL, Kraus VB. Colchicine: Update on mechanisms of action and therapeutic uses. Semin Arthritis Rheum 2015; 45: 341-350.

18. Imazio M, Andreis A, Brucato A, Adler Y, De Ferrari GM. Colchicine for acute and chronic coronary syndromes. Heart 2020; 106: $1555-1560$.

19. Ridker PM, Everett BM, Thuren T, MacFadyen JG, Chang WH, Ballantyne C, et al. Antiinflammatory therapy with canakinumab for atherosclerotic disease. $N$ Engl J Med 2017; 377: 1119-1131.

20. Samuel M, Tardif JC, Bouabdallaoui N, Khairy P, Dubé MP, Blondeau L, et al. Colchicine for secondary prevention of cardiovascular disease: A systematic review and meta-analysis of randomized controlled trials. Can J Cardiol 2021; 37: 776-785.

21. Shah B, Toprover M, Crittenden DB, Jeurling S, Pike VC, Krasnokutsky S, et al. Colchicine use and incident coronary artery disease in male patients with gout. Can J Cardiol 2020; 36: $1722-1728$.

22. Samuel M, Tardif JC, Khairy P, Roubille F, Waters DD, Grégoire JC, et al. Cost-effectiveness of low-dose colchicine after myocardial infarction in the Colchicine Cardiovascular Outcomes Trial (COLCOT). Eur Heart J Qual Care Clin Outcomes, doi:10.1093/ ehjqcco/qcaa045.

\section{Supplementary Files}

Please find supplementary file(s);

http://dx.doi.org/10.1253/circrep.CR-21-0065 